\title{
KEANEKARAGAMAN, DOMINASI, PERSEBARAN SPESIES PENGGEREK BATANG PADI DAN SERANGANNYA PADA BERBAGAI TIPOLOGI LAHAN DI PROVINSI JAMBI
}

\author{
Wilyus $^{1}$, Fuad Nurdiansyah ${ }^{1}$, Asni Johari², Siti Herlinda ${ }^{3}$, Chandra Irsan $^{3}$, \& Yulia Pujiastuti ${ }^{3}$ \\ ${ }^{1}$ Fakultas Pertanian Universitas Jambi \\ ${ }^{2}$ FKIP Universitas Jambi \\ ${ }^{3}$ Fakultas Pertanian Universitas Sriwijaya \\ E-mail: wilyus_hpt@yahoo.co.id
}

\begin{abstract}
Diversity, domination, and distribution of rice stem borer species and its damage in various land typologies in Jambi Province. The research was conducted to analyze the diversity, domination, species distribution of rice stem borers (RSB) and its damage on various land typologies in Jambi Province. The research was carried out using survey method, from December 2010 until June 2011. Samples of RSB were collected from tidal swamp in Tanjung Jabung Timur District, swampy area in Muaro Jambi District, rainfed lowland in Sarolangun District, irrigated lowland in Merangin District, and irrigated upland in Kerinci District and Sungai Penuh District. The results showed that there were five spesies of RSB found in Jambi Province. Scirpophaga incertulas Walker (yellow stem borer) was the most dominant of RSB, followed by Sesamia inferens Walker (pink stem borer), Chilo suppressalis Walker (striped stem borer), Chilo polychrysus Meyrick (dark-headed stem borer), and Scirpophaga innotata Walker (white stem borer). The distribution of S. incertulas, S. inferens, C. suppressalis and C. polychrysus were in all of rice field in Jambi Province, but that of S. innotata was limited over tidal swamp and rainfield lowland area. The RSB damage rate was lower than economic thereshold.
\end{abstract}

Key words: diversity, distribution, domination, rice stem borer

\begin{abstract}
ABSTRAK
Keanekaragaman, dominasi, persebaran spesies penggerek batang padi dan serangannya pada berbagai tipologi lahan di Provinsi Jambi. Penelitian dilakukan untuk menganalisis keanekaragaman, dominasi, persebaran spesies penggerek batang padi (PBP) dan serangannya pada berbagai tipologi lahan di Provinsi Jambi. Penelitian dilakukan dengan metode survei, dari bulan Desember 2010 sampai Juni 2011. Sampel PBP diambil dari sawah pasang surut di Kabupaten Tanjung Jabung Timur, sawah rawa lebak di Kabupaten Muaro Jambi, sawah tadah hujan di Kabupaten Sarolangun, sawah irigasi dataran rendah di Kabupaten Merangin, dan sawah irigasi dataran tinggi di Kabupaten Kerinci dan Kota Sungai Penuh. Hasil penelitian menunjukkan bahwa di Provinsi Jambi terdapat lima spesies PBP, yang paling dominan adalah PBP kuning (Scirpophaga incertulas Walker), diikuti oleh PBP merah jambu (Sesamia inferens Walker), PBP bergaris (Chilo suppressalis Walker), PBP kepala hitam (Chilo polychrysus Meyrick), dan PBP putih (Scirpophaga innotata Walker). Keempat spesies pertama tersebar di seluruh daerah pertanaman padi di Provinsi Jambi sedangkan S. innotata tersebar pada daerah yang terbatas yaitu di daerah pasang surut dan tadah hujan. Tingkat serangan PBP rendah (di bawah ambang ekonomi).
\end{abstract}

Kata kunci: keanekaragaman, persebaran, dominasi, penggerek batang padi

\section{PENDAHULUAN}

Penggerek batang padi (PBP) merupakan hama penting pada tanaman padi yang secara nyata dapat menyebabkan penurunan hasil (Jaipla et al., 2005). Syam et al. (2007) menegaskan bahwa PBP merupakan hama paling penting pada tanaman padi. Di Provinsi Jambi hama ini menyerang tanaman padi di seluruh wilayah, dengan intensitas kerusakan bervariasi dari ringan, sedang, berat sampai puso (UPTD BPTPH
Dinas Pertanian Tanaman Pangan Provinsi Jambi 2006, 2007, 2008).

Di Indonesia ditemukan beberapa spesies PBP yang tergolong dalam dua famili yaitu famili Pyralidae; PBP kuning (Scirpophaga incertulas Walker), PBP bergaris (Chilo suppressalis Walker), PBP putih (Scirpophaga innotata Walker), dan PBP kepala hitam (Chilo polychrysus Meyrick), dan famili Noctuidae; PBP merah jambu (Sesamia inferens Walker) (Kalshoven, 1981). Di negara lain juga telah dilaporkan 
berbagai spesies PBP, misalnya di Afrika Selatan; PBP bergaris Afrika Chilo zacconius Bleszinski, PBP putih Afrika Maliarpha separatella Ragonot, Scirpophaga spp, dan PBP merah jambu Afrika Sesamia calamistis Hampson, Sesamia nonagrioides batanephaga Tams and Bouden (Heindrichs \& Barrion, 2004). Jaipla et al. (2005) melaporkan bawa di India PBP yang umum ditemukan adalah $S$. incertulas, $S$. innotata, $S$. inferens dan $C$. polychrysus.

Dale (1994) menyatakan bahwa $S$. incertulas dan $S$. innotata merupakan hama penting di berbagai wilayah dunia dan tersebar luas baik pada dataran rendah maupun dataran tinggi. Salim et al. (2001) melaporkan bahwa dari data pengamatan PBP selama 25 tahun di Provinsi Punjab Pakistan menunjukkan bahwa 95\% dari PBP tergolong ke dalam Scirpophaga spp. Siwi et al. (2004) menyatakan bahwa PBP yang paling merusak dan banyak menimbulkan kerugian di Indonesia dan negara-negara produsen padi lainnya adalah $S$. incertulas dan $S$. innotata. Kurniawati \& Suharto (2010) menginformasikan bahwa $S$. incertulas merupakan PBP yang paling dominan menyerang tanaman padi. Moiz \& Rizvi (1971) melaporkan bahwa selama tahun 1968 sampai 1969 di Daerah Pesisir dan Larkana S. inferens mendominasi $33 \%$ dari empat spesies PBP yang ditemukan.

Persebaran dan perkembangan populasi PBP pada pertanaman padi dipengaruhi oleh berbagai faktor abiotik dan biotik. Kalshoven (1981) menyatakan bahwa di pulau Jawa PBP putih hanya ditemukan pada dataran rendah sampai ketinggian 200 meter dari permukaan laut. S. innotata dapat mempertahankan diri dalam keadaan lingkungan tidak baik (kekeringan yang panjang) dengan mengalami diapause larva dan pada saat air atau kelembaban cukup masa diapause akan segera berakhir. Sasromarsono (1990) menyatakan bahwa berakhirnya masa diapause dapat memicu terjadinya ledakan hama. Tamrin \& Asikin (2004) melaporkan bahwa $S$. innotata dominan di daerah pasang surut dan $S$. incertulas dominan di lahan lebak dan tadah hujan di Kalimantan Selatan.

Pada agroekosistem padi berbagai faktor biotik berupa musuh alami (predator, parasitoid dan patogen) dapat menekan perkembangan populasi PBP. Wilyus et al. (2012) melaporkan bahwa di Provinsi Jambi terdapat tiga spesies parasitoid telur PBP yaitu T. rowani, T. schoenobii dan T. japonicum, dengan proporsi telur terparasit oleh ketiga jenis parasitoid tersebut adalah 31,44\%. Menurut Shepard et al. (1991) predator yang berperan dalam mengendalikan PBP ialah Metioche vittaticollis Stal, Anaxipha longipennis Serville,
Conocephalus longipennis (de Haan), Polytoxus fuscovitatus Stal, Agriognemis pycmaea Ramburt, Euborellia stall Dohrn, Solenosis geminata Fabricius, Lycosa pseudoannulata Boesemberg dan Strand, Oxyopes javanus Thorell, dan Oxypes lineatipes CL Koch. Parasitoid yang berperan mengendalikan PBP ialah Tetrastichus schoenobii Ferriere, Telenomus rowani Gahan dan Trichogramma japonicum Ashmead (Rauf, 2000; Ardjanhar et al., 2004; Hamijaya et al., 2004; Wilyus, 2009; Wilyus et al., 2012), Itoplectis narangae Ashmead, Xanthopimpla flavolineata Carmeron, Temelucha philippinensis Ashmead, Stenobracon nicevillei Bingham, Cotesia flavipes Cameron dan Phanerotoma sp. (Shepard et al., 1991). Patogen yang berperan mengendalikan PBP ialah Beauveria bassiana Balsamo Vuellemin dan Nomuraea rileyi Farlow Samson (Shepard et al., 1991).

Pengendalian PBP di Provinsi Jambi masih bertumpu pada penggunaan insektisida sintetik. Penggunaan insektisida ternyata tidak efektif, terbukti dengan serangan dan kerugian oleh hama tersebut meningkat dari tahun ke tahun. Di samping itu penggunaan insektisida juga dapat menimbulkan berbagai dampak negatif terhadap konsumen dan lingkungan, serta dapat menimbulkan resistensi dan resurgensi hama. Informasi tentang keanekaragaman spesies PBP, dominasi, persebaran dan serangan PBP sangat dibutuhkan untuk mengembangkan teknik pengendalian hama ini secara lebih tepat.

Untuk menanggulangi masalah tersebut, diperlukan upaya pengendalian melalui pengelolaan hama terpadu (PHT) yang menekankan upaya pengendalian hayati (pemanfaatan musuh alami). Pelaksanaan PHT harus didukung oleh pengetahuan dan pemahaman yang holistik dan komprehensif tentang biologi, ekologi dan ekonomi hama (Untung, 2006). Dalam PHT penggunaan insektisida sebagai alternatif terakhir, jika populasi hama telah mencapai ambang ekonomi (AE). AE PBP ialah dua kelompok telur/20 rumpun padi sebelum pengisian malai atau satu kelompok telur/20 rumpun padi pada saat pengisian malai (Untung, 2006). Berdasarkan kerusakan tanaman, AE PBP ialah $20 \%$ gejala sundep atau $10 \%$ gejala beluk (Reissig et al., 1985).

Masih sangat sedikit informasi tentang keanekaragaman spesies PBP, dominasi, persebaran dan serangan PBP di Provinsi Jambi. Penelitian ini bertujuan untuk mengetahui keanekaragaman, persebaran dan dominasi spesies PBP serta tingkat serangannya di Provinsi Jambi. 


\section{METODE PENELITIAN}

Penelitian dilaksanakan pada berbagai tipologi lahan sawah di Provinsi Jambi (Tabel 1), dari bulan Desember 2010 sampai Juni 2011.

\section{Pengamatan Keanekaragaman, Dominasi, dan} Persebaran Spesies Penggerek Batang Padi. Keanekaragaman spesies PBP, persebaran dan dominasinya ditentukan dengan mengumpulkan larva instar III, IV dan pupa PBP. Pengumpulan larva dan pupa dilakukan di tanaman padi fase vegetatif dan generatif yang terdapat di berbagai tipologi lahan sawah (Tabel 1). Pengambilan sampel dilakukan melalui eksplorasi. Eksplorasi dilakukan pada garis diagonal yang ditetapkan pada lokasi penelitian. Pada setiap daerah sampel dikumpulkan minimal 25 ekor larva instar III, IV dan pupa. Larva dan pupa diambil dengan membelah batang padi yang bergejala sundep atau beluk. Larva dan pupa yang didapatkan dimasukkan ke dalam botol yang berdiameter $3,5 \mathrm{~cm}$ dan tinggi $5 \mathrm{~cm}$ (satu botol berisi satu individu). Pada botol diberi label yang menunjukkan tempat dan tanggal pengambilan sampel.

Sampel pada botol yang berlabel itu kemudian dibawa ke laboratorium untuk dipelihara. Selama pemeliharaan di laboratorium larva diberi potongan batang padi segar untuk makanannya. Identifikasi spesies PBP dilakukan secara bertingkat mulai dari larva, pupa sampai ngengat yang muncul dari hasil pemeliharaan. Imago yang muncul dari hasil pemeliharaan dimatikan dengan KCN. Imago tersebut kemudian dikeringkan untuk diidentifikasi. Spesies PBP yang ditemukan dan jumlah masing-masing spesies dicatat dan difoto dengan kamera digital. Identifikasi spesies PBP dilakukan berdasar ciri-ciri morfologi dan buku mengacu pada Kalshoven (1981), Catindig \& Heong (2003).

Data yang diperoleh dianalisis dengan menghitung jumlah spesies PBP, proporsi setiap spesies, menentukan indeks Shannon (Ludwig \& Reynolds, 1988; Maguran, 1988), Indeks Berger-Parker (Southwood,
1980; Maguran, 1988), Indeks Kemerataan (Ludwig \& Reynolds, 1988).

\section{Pengamatan Serangan Penggerek Batang Padi.} Pengamatan serangan PBP dilakukan pada tanaman padi fase vegetatif dan generatif pada berbagai tipologi lahan (Tabel 1). Metode pengambilan sampel dilakukan secara sistematik. Pada setiap daerah sampel ditentukan 5 petak sampel. Pada setiap petak sampel terdiri dari 16 rumpun padi. Pada setiap petak diamati gejala sundep dan beluk. Dalam pengamatan dicatat: jumlah tanaman padi yang menunjukkan gejala sundep, jumlah tanaman padi yang menunjukkan gejala beluk, dan jumlah tanaman padi setiap petak. Kemudian dihitung tingkat serangan sundep dan beluk dengan membagi jumlah tanaman terserang dengan jumlah tanaman diamati dikali $100 \%$. Data yang diperoleh dianalisis secara deskriptif.

\section{HASIL DAN PEMBAHASAN}

\section{Keanekaragaman Spesies Penggerek Batang Padi} di Provinsi Jambi. Pada pertanaman padi di sawah pasang surut dan sawah tadah hujan ditemukan lima spesies PBP yaitu $S$. incertulas, $S$. inferens, $C$. suppressalis, $C$. polychrysus, dan $S$. innotata. Morfologi ngengat dari masing-masing spesies PBP dapat dilihat pada Gambar 1. Sayap depan ngengat $S$. incertulas berwarna coklat terang sampai kekuningkuningan, dengan bintik hitam yang jelas di tengahtengahnya. Abdomen S. incertulas lebar dan pada ujungnya ditumbuhi rambut-rambut yang berwarna kekuningan. Ngengat $S$. inferens berwarna coklat terang. Pada sayap depan S. inferens terdapat pita berwarna merah keungu-unguan yang melingkar dari titik pusat dari sayap depan menuju ujung sayap. Sayap belakang $S$. inferens berwarna keputih-putihan. Ngengat $C$. suppressalis berwarna kuning kecoklatan. Pada masing-masing sayap depan $C$. suppressalis terdapat satu baris titik hitam kecil diujungnya dan lima baris strip berwarna coklat. Barisan titik hitam kecil yang terdapat di ujung masing-masing sayap depan

Tabel 1. Deskripsi daerah tempat pengambilan sampel penggerek batang padi di Provinsi Jambi

\begin{tabular}{lcl}
\hline $\begin{array}{l}\text { Daerah sampel } \\
\text { Kabupaten/Kota) }\end{array}$ & Ketinggian dari permukaan laut $(\mathrm{m})$ & Tipologi lahan \\
\hline Tanjung Jabung Timur & $0-10$ & Pasang surut \\
Muaro Jambi & $10-20$ & Rawa lebak \\
Sarolangun & $30-50$ & Tadah hujan \\
Merangin & $50-200$ & Irigasi teknis dataran rendah \\
Kerinci dan Sungai Penuh & $750-850$ & Irigasi teknis dataran tinggi \\
\hline
\end{tabular}


tersebut berjumlah 7 atau 8 buah. Ngengat $C$. polychrysus berwarna kuning kecoklatan. Pada masing-masing sayap depan C. polychrysus terdapat satu baris titik hitam kecil di ujungnya dan 6-7 sisi berwarna perak. Sayap belakang C. polychrysus berwarna putih kekuning-kuningan. Ngengat $S$. innotata berwarna putih bersih dan mempunyai tanda rambut yang panjang di atas torak.

Morfologi larva dari masing-masing spesies PBP erat kaitannya dengan nama umumnya (Gambar 2). Tubuh larva $S$. incertulas berwarna hijau kekuningan, dan kepalanya berwarna coklat. Tubuh larva $S$. inferens sebelah dorsal berwarna merah jambu muda, dan sebelah lateral berwarna merah jambu muda sampai putih. Kepala larva $S$. inferens berwarna merah jambu kecoklatan. Tubuh Larva $C$. suppressalis berwarna abu-abu atau abu-abu agak krem. Pada tubuhnya terdapat 5 buah garis berwarna coklat. Garis tersebut terdapat dibagian dorsal dan lateral sejajar tubuhnya. Kepala larva $C$. suppressalis berwarna coklat. Tubuh larva $C$. polychrysus berwarna krem kecoklatan, dan kepalanya berwarna hitam. Tubuh larva $S$. innotata berwarna putih atau putih kekuningan, dan kepalanya berwarna coklat.

Pupa PBP memiliki ciri morfologi yang khas. Pupa $S$. incertulas berwarna hijau pucat atau putih kehijauan yang ditutupi oleh kokon berupa selaput benang atau sutra berwarna putih. Pupa $S$. inferens berwarna coklat atau coklat tua. Pupa $C$. suppressalis berwarna coklat kemerahan, dan pada segmen terakhir terdapat dua benjolan pendek seperti duri. Pupa C. polychrysus berwarna coklat kekuningan atau coklat terang, dan

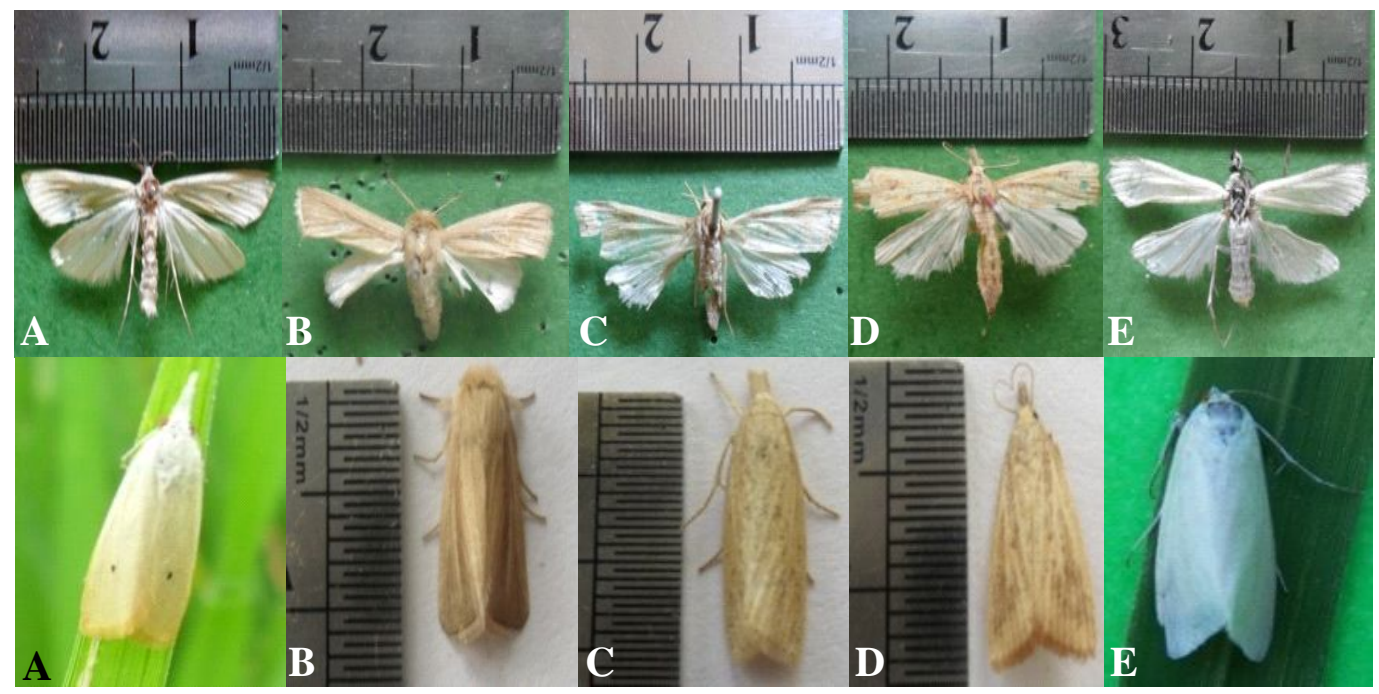

Gambar 1. Ngengat Scirpophaga incertulas (A), Sesamia inferens (B), Chilo suppressalis (C), Chilo polychrysus (D), Scirpophaga innotata (E).
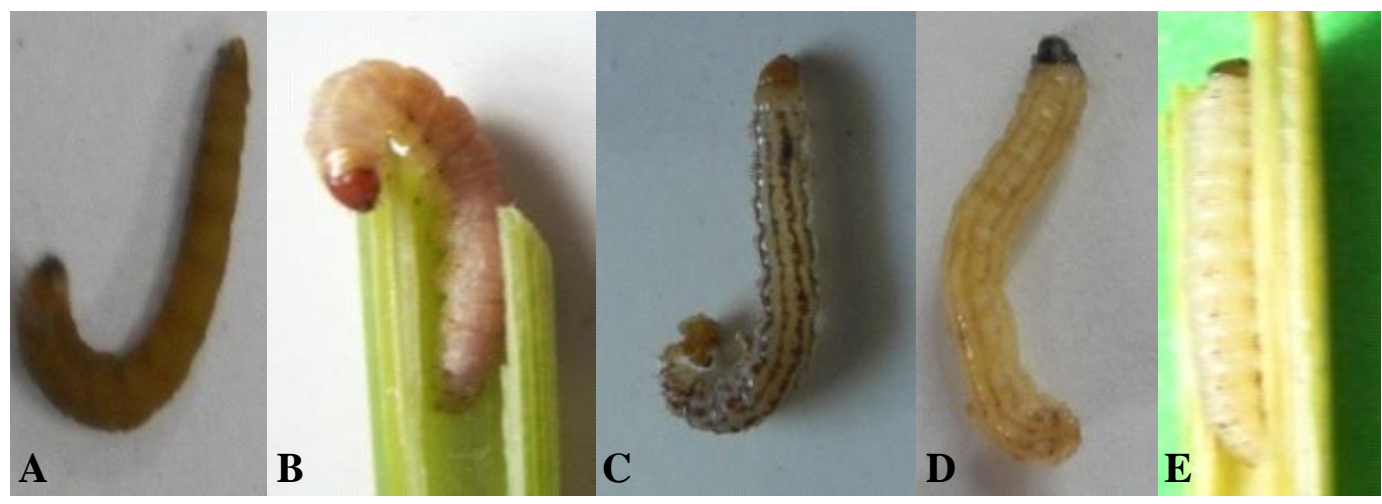

Gambar 2. Larva Scirpophaga incertulas (A), Sesamia inferens (B), Chilo suppressalis (C), Chilo polychrysus (D), Scirpophaga innotata (E). 
mempunyai duri yang runcing pada abdomen segmen terakhir. Pupa $S$. innotata berwarna agak putih sampai coklat (Gambar 3).

Pada pertanaman padi di sawah rawa lebak, sawah irigasi teknis dataran rendah dan sawah irigasi teknis dataran tinggi ditemukan empat spesies PBP yaitu $S$. incertulas, $S$. inferens, $C$. suppressalis dan $C$. polychrysus. Pada pertanaman padi di sawah pasang surut dan tadah hujan ditemukan lima spesies PBP yaitu $S$. incertulas, $S$. inferens, $C$. suppressalis, $C$. polychrysus, dan S. innotata. Tamrin dan Asikin (2004) melaporkan bahwa di lahan pasang surut, lahan lebak dan lahan tadah hujan di Kalimantan Selatan ditemukan dua spesies PBP yaitu $S$. innotata dan $S$. incertulas. Semua spesies PBP di Indonesia yang dikemukakan oleh Kalshoven (1981) ditemukan di Jambi. Artinya berbagai daerah pertanaman padi di Provinsi Jambi merupakan wilayah yang potensial untuk berkembangnya PBP. Oleh karena itu keberadaan hama ini di Provinsi Jambi perlu diwaspadai.

tipologi lahan sawah tadah hujan paling tinggi dibandingkan dengan nilai Indeks Shanon komunitas PBP pada tipoloogi lahan sawah yang lain (Tabel 2). Tingginya keanekaragaman spesies PBP pada pertanaman padi di sawah tadah hujan disebabkan oleh habitat sawah tadah hujan dan karakteristik ekosistem
Dominasi Spesies Penggerek Batang Padi. Dominasi spesies PBP di masing-masing tipologi lahan sawah relatif sama (Gambar 4). Spesies PBP yang paling dominan adalah $S$. incertulas. Urutan dominasi spesies PBP berikutnya berturut-turut adalah $S$. inferens, $C$. suppressalis, C. polychrysus, dan S. innotata.

Populasi $S$. innotata di berbagai tipologi sawah di Provinsi Jambi tergolong rendah dibandingkan dengan spesies PBP yang lain. Informasi tersebut berbeda dengan pernyataan Siwi et al. (2004) bahwa S. innotata termasuk spesies PBP yang dominan dan merugikan tanaman padi di berbagai Provinsi Indonesia. Siwi et al. (2004) menyatakan bahwa PBP yang paling merusak dan banyak menimbulkan kerugian di Indonesia dan negara-negara produsen padi lainnya ialah $S$. incertulas dan S. innotata.

Informasi baru yang didapat dari penelitian ini adalah keberadaan $S$. inferens. Sampai saat ini belum ada laporan yang menjelaskan bahwa $S$. inferens termasuk PBP yang perlu diwaspadai. Keberadaan $S$. inferens pada berbagai tipe sawah di Provinsi Jambi cukup dominan setelah S. incertulas (Gambar 4). Proporsi spesies $S$. inferens di Provinsi Jambi berkisar dari $28 \%$ sampai $38 \%$. Oleh sebab itu keberadaan $S$. inferens di Provinsi Jambi bahkan mungkin juga di daerah lain perlu diwaspadai.

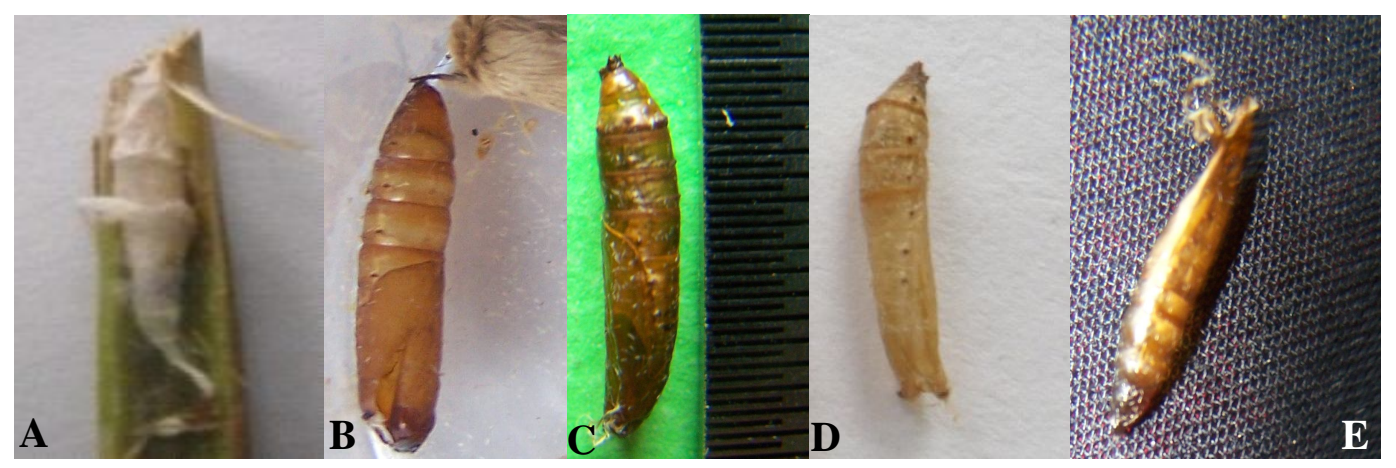

Gambar 3. Pupa Scirpophaga incertulas (A), Sesamia inferens (B), Chilo suppressalis (C), Chilo polychrysus (D), Scirpophaga innotata (E).

Tabel 2. Karakteristik komunitas penggerek batang padi pada berbagai tipologi lahan sawah di Provinsi Jambi

\begin{tabular}{lrrrrr}
\hline \multirow{2}{*}{ Karakteristik komunitas } & Pasang surut & Rawa lebak & Tadah hujan & \multicolumn{2}{c}{ Irigasi teknis } \\
\cline { 5 - 6 } & & & & Dataran rendah & Dataran tinggi \\
\hline Jumlah spesimen (ekor) & 330,000 & 324,000 & 208,000 & 334,000 & 303,000 \\
Jumlah spesies & 5,000 & 4,000 & 5,000 & 4,000 & 4,000 \\
Indeks Shanon & 0,943 & 0,933 & 1,088 & 0,941 & 0,725 \\
Indeks Berger-Parker & 0,567 & 0,549 & 0,563 & 0,590 & 0,693 \\
Indeks Kemerataan & 0,586 & 0,673 & 0,676 & 0,679 & 0,523 \\
\hline
\end{tabular}


Persebaran Spesies Penggerek Batang Padi. Hasil pengamatan menunjukkan bahwa; persebaran spesies S.incertulas, S.inferens, C.suppressalis, $C$. polychrysus tidak dipengaruhi oleh tipologi lahan sawah. Keempat spesies PBP ini ditemukan pada semua tipologi lahan sawah (pasang surut, rawa lebak, tadah hujan, irigasi teknis dataran rendah dan irigasi teknis dataran tinggi) di di Provinsi Jambi. S. innotata yang hanya ditemukan di sawah pasang surut dan tadah hujan (Tabel 3). Kalshoven (1981) menyatakan bahwa S. innotata memiliki daerah penyebaran lebih terbatas dibandingkan dengan daerah penyebaran $S$. incertulas, yaitu di daerah dataran rendah sampai ketinggian 200 m dari permukaan laut.

Pada penelitian ini S. innotata tidak ditemukan pada sawah rawa lebak di Kabupaten Muaro Jambi dan sawah irigasi teknis dataran rendah di Kabupaten Merangin, sedangkan daerah ini masih berada pada ketinggian $\geq 200$ m dari permukan laut. Tidak ditemukan $S$. innotata di daerah ini dapat disebabkan oleh teknik budidaya padi yang dipraktekkan. Pada lahan rawa lebak ada masa pemberoan sawah saat musim banjir selama beberapa bulan, dan pada sawah irigasi teknis dataran rendah dilakukan penggenangan dan pelumpuran sawah saat pengolaan tanah. Kedua proses tersebut dapat memutus siklus hidup $S$. innotata.

Serangan Penggerek Batang Padi. Hasil pengamatan pada pertanaman padi yang dilakukan pada periode Desember 2010 sampai Juni 2011 menunjukkan bahwa tingkat serangan PBP pada periode ini tergolong rendah (Tabel 4), jauh dibawah ambang ekonomi. Ambang ekonomi PBP adalah 20\% tanaman menunjukkan gejala sundep atau $10 \%$ tanaman menunjukkan gejala beluk (Reissig et al., 1985).

Keanekaragaman spesies PBP di berbagai wilayah di Provinsi Jambi tinggi, namun tingkat kerusakan yang ditimbulkannya rendah, jauh di bawah ambang ekonomi. Hal itu menunjukkan bahwa populasi PBP tidak berkembang ke tingkat yang merugikan secara
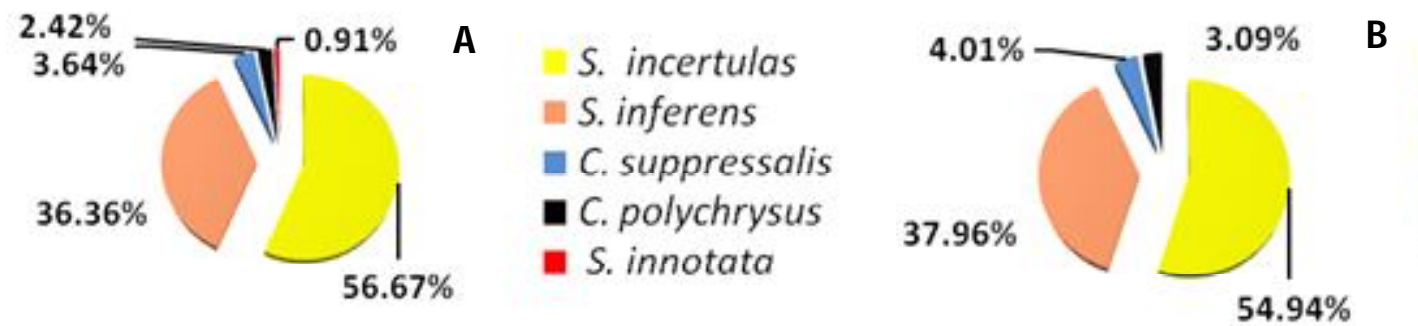
S. incertulas
S. inferens
C. suppressalis
- C. polychrysus

$54.94 \%$
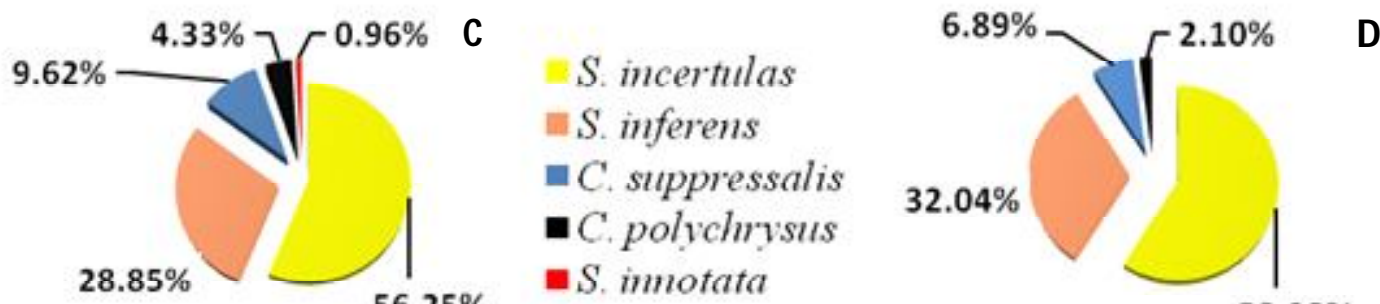

\section{S. incertulas \\ a. inferens \\ C. suppressalis \\ C. polychrysus}

$58.98 \%$

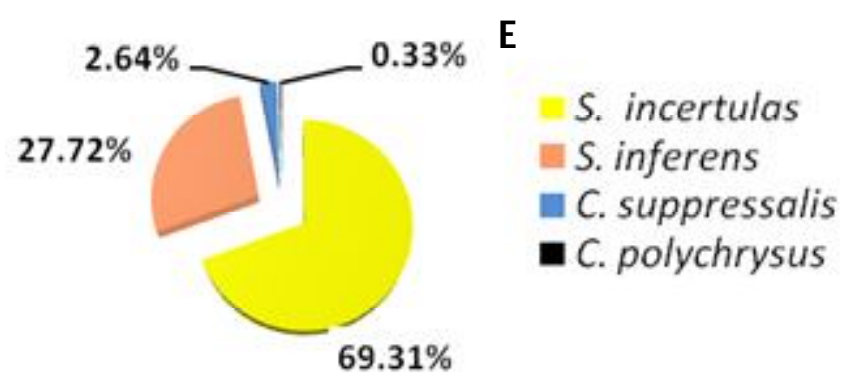

Gambar 4. Proporsi populasi larva penggerek batang padi pada berbagai tipologi lahan sawah di Provinsi Jambi. (A) Lahan pasang surut, (B) lahan rawa lebak, (C) lahan tadah hujan, (D) lahan irigasi teknis dataran rendah, dan (E) lahan irigasi teknis dataran tinggi. 
ekonomi. Sebelumnya UPTD BPTPH Provinsi Jambi (2006, 2007, 2008) melaporkan bahwa di Provinsi Jambi PBP menyerang tanaman padi di seluruh wilayah, dengan intensitas kerusakan bervariasi dari ringan, sedang, berat sampai puso.

Tidak berkembangnya populasi PBP dapat disebabkan oleh berbagai fakor, diantaranya adalah peran musuh alami dalam mengendalikan hama ini. Dalam rangkaian penelitian ini juga diamati dan dilaporkan potensi dan peranan parasitoid telur PBP di lapang. Dari penelitian yang sudah dilakukan diketahui bahwa pada berbagai tipologi lahan sawah di Provinsi Jambi terdapat tiga spesies parasitoid telur PBP yaitu $T$. rowani, T. schoenobii dan T. japonicum, dengan proporsi telur terparasit oleh ketiga jenis parasitoid tersebut adalah 31,44\% (Wilyus et al., 2012).

Shepard et al. (1991) menayatakan bahwa pada agroekosistem padi, spesies musuh alami (predator, parasitoid dan patogen) berperan penting dalam menekan perkembangan populasi PBP. Predator yang berperan dalam mengendalikan PBP ialah $M$. vittaticollis, A. longipennis, C. longipennis, $P$. fuscovitatus, A. pycmaea, E. stall, S. geminata, L. pseudoannulata, O. javanus, dan O. lineatipes (Shepard et al., 1991). Parasitoid yang berperan mengendalikan PBP ialah $T$. schoenobii, T. rowani dan T. japonicum (Rauf, 2000; Ardjanhar et al., 2004; Hamijaya et al., 2004), I. narangae, X. flavolineata, T. philippinensis, $S$. nicevillei, C. flavipes dan Phanerotoma sp. (Shepard et al., 1991). Patogen yang berperan mengendalikan PBP ialah B. bassiana dan N. rileyi (Shepard et al., 1991). Parasitoid telur yang berperan mengendalikan PBP di provinsi Jambi ialah $T$. schoenobii, $T$. rowani dan T. japonicum (Wilyus, 2009).

\section{SIMPULAN}

Di Provinsi Jambi terdapat lima spesies PBP yaitu $S$. incertulas, $S$. inferens, $C$. suppressalis, $C$. polychrysus dan $S$. innotata, yang paling dominan adalah $S$. incertulas, dan diikuti oleh $S$. inferens. Kelima spp. tersebut tersebar di seluruh daerah pertanaman padi kecuali $S$. innotata yang hanya ditemukan di lahan pasang surut dan tadah hujan. Tingkat serangan PBP tergolong rendah dan berada di bawah ambang ekonomi.

\section{SANWACANA}

Terimakasih disampaikan kepada Direktorat Jenderal Pendidikan Tinggi, Kementerian Pendidikan Nasional atas dukungan dana Hibah Bersaing yang diberikan sesuai dengan Surat Perjanjian Pelaksanaan Penugasan Nomor:017/SP2H/PL/Dit.Litabmas/IV/2011 Tanggal 14 April 2011.

Tabel 3. Persebaran spesies penggerek batang padi pada berbagai tipologi lahan tanaman padi di Provinsi Jambi

\begin{tabular}{|c|c|c|c|c|c|}
\hline \multirow{2}{*}{ Spesies } & \multirow{2}{*}{ Pasang surut } & \multirow{2}{*}{ Rawa lebak } & \multirow{2}{*}{ Tadah hujan } & \multicolumn{2}{|c|}{ Irigasi teknis } \\
\hline & & & & Dataran rendah & Dataran tinggi \\
\hline Scirpophaga incertulas & + & + & + & + & + \\
\hline Sesamia inferens & + & + & + & + & + \\
\hline Chilo suppressalis & + & + & + & + & + \\
\hline Chilo polychrysus & + & + & + & + & + \\
\hline Scirpophaga innotata & + & - & + & - & - \\
\hline
\end{tabular}

$+=$ ditemukan, - = tidak ditemukan

Tabel 4. Persentase serangan PBP pada berbagai tipologi lahan sawah di Provinsi Jambi

\begin{tabular}{lcc}
\hline \multirow{2}{*}{ Ekosistem (Kabupaten) } & \multicolumn{2}{c}{ Tingkat serangan (\%) } \\
\cline { 2 - 3 } & Sundep & Beluk \\
\hline Pasang surut (Tanjung Jabung Timur) & 1,9 & 2,0 \\
Rawa lebak (Muaro Jambi) & 1,9 & 0,6 \\
Tadah hujan (Sarolangun) & 1,6 & 0,7 \\
Irigasi teknis dan tadah hujan (Merangin) & 2,3 & 1,7 \\
Irigasi teknis (Kerinci/Sungai Penuh) & 1,3 & 1,0 \\
\hline
\end{tabular}




\section{DAFTAR PUSTAKA}

Ardjanhar A, Siwi SS, \& Mahrub E. 2004. Peranan parasitoid telur penggerek batang padi pada lahan yang diaplikasi insektisida kimia di daerah Indramayu. hlm 471-484 Di dalam Prosiding Seminar Nasional Entomologi dalam Perubahan Lingkungan Sosial. Bogor, 5 Oktober 2004.

Catindig JLA \& Heong KL. 2003. Stem Borers. IRRI. Los Banos.

Dale D. 1994. Insect pest of rice plants-their biology and ecology. Hal 363-485. .In Biology and Managment of Rice Insects (Ed. Heinrichs EA). IRRI. Wiley Eastern Ltd.

Hamijaya MZ, Tamrin M, \& Asikin S. 2004. Dominasi spesies parasitoid telur penggerek batang padi pada tipologi lahan basah di Kalimantan Selatan. hlm 467-474. Di dalam Prosiding Seminar Nasional Entomologi dalam Perubahan Lingkungan Sosial. Bogor, 5 Oktober 2004.

Heindrichs EA, \& Barrion AT. 2004. Rice-Feeding Insects And Selected Natural Enemies In West Africa. Biology, Ecology, Identification. IRRI. Los Banos.

Jaipla S, Malik RK, Yadav A, \& Gupta RK. 2005. IPM Issues in Zerro-Tillage System in Rice-Wheat Cropping Sequence. Bul Tecnical. CCS Haryana Agricultural University. India.

Kalshoven LGE. 1981. The Pests of Crops in Indonesia. Laan PA van der, penerjemah. Jakarta. Ichtiar Baru-Van Hoeve. Terjemahan dari: De Plagen van de Cultuurgewassen in Indonesie.

Kurniawati N \& Syharto H. 2010. Status spesies penggerek batang padi di Jawa Barat. hlm 299307. Di dalam Prosiding Seminar Nasional V Pemberdayaan Keanekaragaman Serangga untuk Meningkatkan Kesejahteraan Masyarakat. Perhimpunan Entomologi Indonesia. Bogor, 5 Mei 2010.

Ludwiq JA \& Reynolds JF. 1988. Statistical Ecology a Primer on Methods and Computing. John Wiley \& Sons. New York.

Maguran AE. 1988. Ecological Diversity and Its Measurement. Cambridge University Press, Cambridge.
Moiz SA \& Rizvi NA. 1971. Ecological studies on Tryporyza incertulas (Walker) in southern part of West Pakistan. pp 19-26. In Proceeding of symposium on Rice Insects. Tokyo Trop.

Rauf A. 2000. Parasitisasi telur penggerek batang padi putih, Scirpophaga innotata (Walker) (Lepidoptera: Piralidae): Saat terjadi ledakan di Kerawang pada awal 1990-an. Bul. HPT 12(1):110.

Reissig WH, Hendrichs EA, Litsinger JA, Moody K, Fiedler R, Mew TW, \& Barrion AT. 1985. Illustrated Guide to Integrated Pest Management in Rice in Tropical Asia. IRRI. Manila, Philipiines.

Salim MS, Masud A, \& Ramzan M. 2001. Integrated pest management of Basmati rice in Pakistan. pp 149-162. In Speciality Rice of the World: Breeding, Production and Marketing. FAO. Rome.

Sasromarsono S. 1990. Bioekologi dan strategi penggendalian terpadu penggerek batang padi putih, Schirpophaga (Tryporiza) inotata Walker (Lepidoptera: Pyralidae). Makalah Disajikan pada Seminar Pengendalian Terpadu Penggerek Batang Padi Putih Dalam Rangka Mempertahankan Swasembada Beras. Bogor, 17 April 1990.

Shepard BM, Barrion AT, \& Litsinger JA. 1991. Serangga, Laba-laba dan Patogen yang Membantu. Cetakan ketujuh. Diterjemahkan oleh Untung K, Wirjosuharjo S dari Helpful insect, Spiders and Phathogens IRRI.

Siwi SS, Ridha N, \& Mahrub E. 2004. Identifikasi jenis penggerek batang padi genus Schirpophaga Treitschke (Lepidoptera: Pyralidae) dari daerah Indramayu dan Maros. hlm 357-370. Di dalam Prosiding Seminar Nasional Entomologi dalam Perubahan Lingkungan Sosial. Bogor, 5 Oktober 2004.

Southwood TRE. 1980. Ecological Methods with Particular Reference to Study of Insect Population. Chapman and Hill. London.

Syam M, Suparyono, Hermanto, \& Wuryandari DS. 2007. Masalah Lapang Hama Penyakit Hara pada Padi. Ed. 3. Puslitbangtan. Bogor. 
Thamrin M \& Asikin S. 2004. Populasi serangga musuh alami pada lingkungan iklim mikro di lahan pasang surut. Prosiding Seminar Nasional Entomologi dalam Perubahan Lingkungan Sosial. Bogor, 5 Oktober 2004. hlm 413-418.

Untung K. 2006. Pengantar Pengelolaan Hama Terpadu. Edisi ke-2. Yogyakarta. Gajah Mada University Press.

UPTD BPTPH Dinas Pertanian Tanaman Pangan Provinsi Jambi. 2006. Data Proteksi Tanaman Pangan dan Hortikultura Tahun 2005. Jambi.

UPTD BPTPH Dinas Pertanian Tanaman Pangan Provinsi Jambi. 2007. Data Proteksi Tanaman Pangan dan Hortikultura Tahun 2006. Jambi.
UPTD BPTPH Dinas Pertanian Tanaman Pangan Provinsi Jambi. 2008. Data Proteksi Tanaman Pangan dan Hortikultura Tahun 2007. Jambi.

Wilyus. 2009. Survey eksplorasi parasitoid telur pengggerek batang padi di Desa Sungai Duren Kecamatan Jambi Luar Kota. 11 hlm. Di dalam Elektronik Journal Proseding Seminar Nasional BKS PTN Wilayah Indonesia Barat. Banten, 13 -15 April 2009.

Wilyus, Nurdiansyah F, Herlinda S, Irsan C, \& Pujiastuti Y. 2012. Potensi parasitoid telur penggerek batang padi kuning Scirpophaga incertulas Walker pada beberapa tipologi lahan di Provinsi Jambi. J. HPT Tropika 12(1):56-63. 